\title{
Questions on unusual Mimivirus-like structures observed in
}

\section{human cells [version 1; peer review: 2 approved]}

\author{
Elena Angela Lusi (D1), Dan Maloney², Federico Caicci (D)3, Paolo Guarascio (D) 4
}

\author{
${ }^{1}$ St Vincent Health Care Group, University College of Dublin, Dublin 4, Ireland \\ ${ }^{2}$ Bioinformatics Solutions Inc., Waterloo, ON, N2L 6J2, Canada \\ ${ }^{3}$ Department of Biology, University of Padua, Padua, 35121, Italy \\ 4Liver Unit, St Camillo Hospital of Rome, Rome, 00152, Italy
}

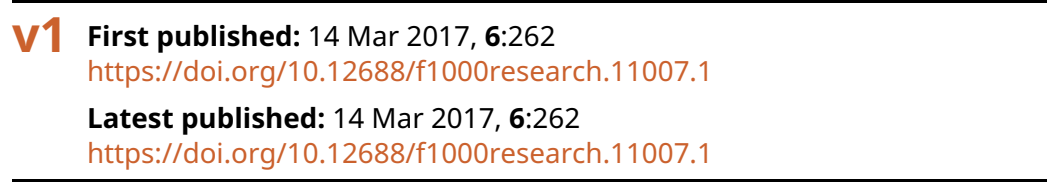

\section{Abstract}

Background: Mimiviruses or giant viruses that infect amoebas have the ability to retain the Gram stain, which is usually used to colour bacteria. There is some evidence suggesting that Mimiviruses can also infect human cells. Guided by these premises, we performed a routine Gram stain on a variety of human specimens to see if we could detect the same Gram positive blue granules that identify Mimiviruses in the amoebas. Methods: We analysed 24 different human specimens (liver, brain, kidney, lymph node and ovary) using Gram stain histochemistry, electron microscopy immunogold, high resolution mass spectrometry and protein identification. Results: We detected in the human cells Gram positive granules that were distinct from bacteria. The fine blue granules displayed the same pattern of the Gram positive granules that diagnose Mimiviruses in the cytoplasm of the amoebas. Electron microscopy confirmed the presence of human Mimiviruses-like structures and mass spectrometry identified histone $\mathrm{H} 4$ peptides, which had the same footprints as giant viruses. However, some differences were noted: the Mimivirus-like structures identified in the human cells were ubiquitous and manifested a distinct mammalian retroviral antigenicity. Conclusions: Our main hypotheses are that the structures could be either giant viruses having a retroviral antigenicity or ancestral cellular components having a viral origin. However, other possible alternatives have been proposed to explain the nature and function of the newly identified structures.

\section{Keywords}

Mimiviruses, human cell structure, histone $\mathrm{H} 4$, retroviral antigen, polydnaviruses

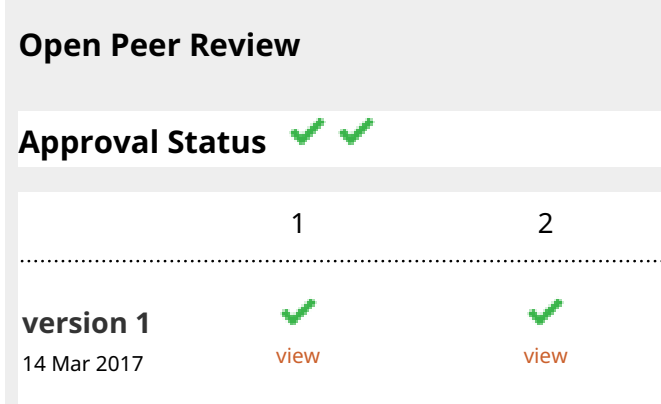

1. Carlo Presutti iD, University of Rome, Rome, Italy

Milena Grossi, Sapienza Università di Roma, Rome, Italy

2. Didier Raoult, Aix-Marseille Université, URMITE, UM63, CNRS7278, IRD198, Inserm 1095, Marseille, France

Any reports and responses or comments on the article can be found at the end of the article. 
Corresponding author: Elena Angela Lusi (elenaangelalusi@yahoo.it)

Competing interests: No competing interests were disclosed.

Grant information: This work was supported by the St Vincent Health Care Group of Dublin.

Copyright: $\odot 2017$ Lusi EA et al. This is an open access article distributed under the terms of the Creative Commons Attribution License, which permits unrestricted use, distribution, and reproduction in any medium, provided the original work is properly cited. Data associated with the article are available under the terms of the Creative Commons Zero "No rights reserved" data waiver (CC0 1.0 Public domain dedication).

How to cite this article: Lusi EA, Maloney D, Caicci F and Guarascio P. Questions on unusual Mimivirus-like structures observed in human cells [version 1; peer review: 2 approved] F1000Research 2017, 6:262 https://doi.org/10.12688/f1000research.11007.1

First published: 14 Mar 2017, 6:262 https://doi.org/10.12688/f1000research.11007.1 


\begin{abstract}
Update:
In this study, we describe the presence of unusual Mimiviruseslike structures in human tissues. Like Mimiviruses ( $\sim 50 \mathrm{~nm}$ giant viruses found in the amoebas), these human structures had the ability to retain the Gram stain and mass spectrometry revealed the presence of histone peptides having the same footprints as giant viruses. However, the human giant viruses-like structures displayed a distinct and unique mammalian retroviral antigenicity.

This initial discovery in human tissues presented the conundrum of whether the structures were giant viruses with a retroviral nature or cellular components having a viral footprint. The distinction between the virus and the cells was blurred. The most difficult part to explain arose from the unique mammalian retroviral antigenicity associated to the human mimivirus-like structures.

There was only one possibility to solve the dilemma: isolate the viruses (if really present) and verify if they contained genetic material. In a subsequent paper https://f1000research.com/ articles/7-1005/v1 we describe:

1. Isolation of human giant viruses from human T-cell leukemia on $25 \%$ sucrose gradient.

2. Electron microscopy of the purified viral pellet confirming the presence of $\sim 400 \mathrm{~nm}$ giant viruses with retroviral antigens.

3. Purified giant viruses retaining the Gram stain.

4. Human giant viruses had reverse transcriptase activity.

5. RNA extracted from the giant viral particles contained retroviral genes (VLPQG-YMDD region of reverse transcriptase gene).

6. Molecular phylogenetic analyses showing that human Retro-Giant viruses belong to a distinct branch, missing from the current classification of retroviruses.
\end{abstract}

Therefore, the Mimivirus-like structures are human giant virus with a retroviral core and oncogenic potential.

We are facing not an archetypal retrovirus, nor even an amoebas DNA mimivirus, but a human, Gram-positive, giant virus (mimiviruslike) with a viral factory and a retroviral core. A preliminary phylogenetic analysis suggests that the Retro-Giant viruses are ancestral and evolved earlier than archetypal retroviruses.

\section{Introduction}

There is evidence that terrestrial giant viruses can also infect mammals and a recent article published on Lancet Infectious Diseases describes the presence of giant viruses in human lymph nodes ${ }^{1-3}$. One of the chemical characteristics of giant viruses is their property to retain the Gram stain, which is usually used to colour bacteria ${ }^{4,5}$.

In fact, Mimiviruses (giant viruses) were initially mistaken for gram-positive bacteria infecting the cytoplasm of an amoeba, which was stuffed with blue Gram positive granules under an optical microscope. Only in 2003 did electron microscopy clarify that the fine blue granules present in the cytoplasm of the amoebas were actually giant viruses ${ }^{6}$.

Guided by the premise that giant viruses can also infect humans, we decided to perform a routine Gram stain on different human specimens to see if we could detect the same blue granules that were detected in the amoeba when Mimiviruses were first identified.

Here we demonstrate, with the use of electron microscopy, mass spectrometry and histochemistry, that human cells have anatomical areas that manifest some of the biochemical and morphological properties also found in giant viruses. These structures are ubiquitously present in a variety of human tissues, including non-pathological tissues. Possible alternative explanations of the findings are discussed.

\section{Methods}

\section{Characteristics of human samples}

- 3 liver specimens with haemochromatosis and non-alcoholic steatohepatitis

- 1 liver specimen with cryptogenic cirrhosis (unexplained)

- 7 liver specimens with chronic hepatitis B

- 2 liver specimens with chronic hepatitis $\mathrm{C}$

- 3 liver specimens with non-specific minimal histological lesions

- 2 liver specimens with no lesions

- 2 liver specimens with primary biliary cirrhosis

- 1 liver specimen from a patient with Crohn's disease

- 1 kidney specimen

- 1 brain specimen

- 1 ovary specimen

The Institutional Review Board of St Camillo Hospital of Rome approved the use of stored tissues for electron microscopy and proteomics investigations in accordance with the Helsinki Declaration of 2002 (approval number, 56/2015). Informed consent were obtained in writing from all patients prior to tissues biopsy procedure, which encompassed processing of the clinical data and the use of tissues for investigation and research. The present study fits within the terms of the obtained consent.

\section{Gram positive staining of human specimens}

Gram staining of human specimens was performed using a Gram Yellow Stain Kit (Artisan from Dako), following the standard protocol for paraffin specimens, according to the manufacturer's instructions. Positive controls were formalin fixed human tissues with bacteria. Before staining, slides were heated at $\underline{80^{\circ} \mathrm{C} \text { for } 45 \text { minutes. }}$

\section{Electron microscopy}

Electron microscopy analysis of the human biopsies was conducted at the University of Naples Federico II, CISME Division and the University of Padua, Department of Biology. The two different operators were blinded to each other's. The samples were fixed with fixative (4\% paraformaldehyde in PBS buffer solution), dehydrated and embedded in LR White Resin followed by polymerization at $58^{\circ} \mathrm{C}$. Ultrathin sections $(100 \mathrm{~nm})$ 
were placed on Formvar-coated nickel grids (Maxtaform Grids; M200-Ni) and used the next day for immunogold labelling. For immunostaining reaction, the post-embedding immunogold method was applied. Nickel grids were immersed in $1 \%$ citraconic anhydride solution (Sigma) at $90^{\circ} \mathrm{C}$ for $30^{\prime}$. Subsequently, the sections were first treated with blocking solution (1\% BSA, $0.1 \%$ Tween 20 , PBS $1 \mathrm{x}$ ), then incubated with primary mouse monoclonal antibody identifying common retroviral antigen among mammalian retrovirus (sc-65623; Santa Cruz Biotecnology; $\mathrm{IgG}_{1}$ provided at $00 \mu \mathrm{g} / \mathrm{ml}$ ) diluted 1:50 for 1 hour at $37^{\circ} \mathrm{C}$. Antibody binding was detected using a secondary goat anti-mouse IgG antibody at room temperature for 1 hour (British BioCell International; EM.GAM15EM), diluted to 1:100 and coupled to gold particles (15nm; British BioCell International). Sections were analyzed using an FEI Tecnai G2 transmission electron microscope operating at $100 \mathrm{kV}$. The images were acquired with TIA Fei software Cam 4.7SP3 (https://www.fei.com/servicesupport/) and collected and typeset in Corel Draw X3 (http://www. coreldraw.com/en/pages/coreldraw-x3/). Controls were performed by omitting the primary antibody, which resulted in absence of cross-reactivity.

\section{Sample preparation for proteomics two dimensional gel electrophoresis}

Human samples were ground with liquid nitrogen. Six volume sample preparation buffer (9M urea, $2 \%$ ampholytes and $70 \mathrm{mM}$ DTT) were added to the frozen powder, followed by three frozen/ thaw cycles (liquid nitrogen $-196^{\circ} \mathrm{C} / 30^{\circ} \mathrm{C}$ ). After incubation for $30 \mathrm{~min}$ at room temperature and centrifugation for $45 \mathrm{~min}$ at $15000 \mathrm{xg}$ the supernatant was removed and frozen in new tubes at $-80^{\circ} \mathrm{C}$. FFPE slices were treated with $0.5 \mathrm{ml}$ Heptan for $1 \mathrm{~h}$ at room temperature. Subsequently, $25 \mu$ methanol were added and mixed for $25 \mathrm{~min}$. After centrifugation (5min, 13200xg) the pellet was air dried and $100 \mu$ lysis-buffer (250 mM Tris $\mathrm{pH} 9.5$; $2 \%$ SDS) were added. The sample was boiled for $2 \mathrm{~h}$, centrifuged (30min, 13200xg, room temperature) and the supernatant was used for SDS-PAGE.

\section{Two dimensional gel electrophoresis}

Two dimensional gel electrophoresis (2DE) was performed according to standard 2DE techniques. Briefly, $50 \mu \mathrm{g}$ of protein was applied to vertical rod gels (9M urea, $4 \%$ acrylamide, $0.3 \%$ PDA, $5 \%$ glycerol, $0.06 \%$ TEMED and $2 \%$ carrier ampholytes [pH 2-11], 0.02\% APS) for isoelectric focusing at $1820 \mathrm{Vh}$ in the first dimension. After focusing, the IEF gels were incubated in equilibration buffer, containing $125 \mathrm{mM}$ trisphosphate $(\mathrm{pH} \mathrm{6.8)}$, $40 \%$ glycerol, $65 \mathrm{mM}$ DTT, and 3\% SDS for 10 minutes and subsequently frozen at $-80^{\circ} \mathrm{C}$. The second dimension SDS-PAGE gels $(7 \times 8 \times 0.1 \mathrm{~cm})$ were prepared, containing $375 \mathrm{mM}$ Tris- $\mathrm{HCl}$ buffer ( $\mathrm{pH} 8.8$ ), $12 \%$ acrylamide, $0.2 \%$ bisacrylamide, $0.1 \%$ SDS and $0.03 \%$ TEMED. After thawing, the equilibrated IEF gels were immediately applied to SDS-PAGE gels. Electrophoresis was performed using $150 \mathrm{~V}$ for 75 min until the front reached the end of the gel. After 2DE separation, the gels were stained with FireSilver (Proteome Factory; PS2001).

The 2DE gels used for comparison analysis were digitized at a resolution of 150 dpi using a PowerLook 2100XL scanner with transparency adapter.

\section{Western blotting}

For western blot applications, two identical gels were run. One 2DE gels was stained with FireSilver or Coomassie for preparative applications and the other gel was used for western blotting to detect the proteins by immunostaining. Blotting of $2 \mathrm{DE}$ gels was performed using an Immobilon-P membrane (PVDF; pore size $0.45 \mathrm{~mm}$; Millipore) and a Trans-Blot SD Semi-Dry Transfer Cell (BioRad) at a constant current $5 \mathrm{~V}$ overnight at $4{ }^{\circ} \mathrm{C}$ using a blotting buffer consisting of $25 \mathrm{mM}$ Tris-HCl, $192 \mathrm{mM}$ glycine, $0.1 \%$ SDS ( $\mathrm{pH} 8.3$ ) and $20 \%$ methanol. For immunodetection of proteins, membranes were washed in TBST $(20 \mathrm{mM}$ Tris- $\mathrm{HCl}$ [pH 7.5]; $154 \mathrm{mM} \mathrm{NaCl}, 0.1 \%$ Tween-20) and blocked in TBST containing $2 \%(\mathrm{w} / \mathrm{v}) \mathrm{BSA}$ for $2 \mathrm{~h}$. Membranes were incubated with the primary antibody (sc-65623; Santa Cruz Biotecnology; $\mathrm{IgG}_{1}$ ) diluted 1:1000 for 2DE blot and 1:50 for 1D-blots in TBST containing $1 \%(\mathrm{w} / \mathrm{v}) \mathrm{BSA}$ overnight and then incubated with antimouse IgG (Fc specific-peroxidase antibody produced in goat; A0168; Sigma; diluted to 1:2000 in TBST containing 1\% (w/v) BSA) for $1 \mathrm{~h}$ at room temperature. Finally, the bound antibody was detected by incubating with Luminol for 1s-20min (Roth). The membrane was washed in TBST ( 5 times for $10 \mathrm{~min}$ ) between all incubation steps.

\section{Trypsin-in-gel-digestion/nanoLC-ESI-MS/MS}

Protein identification was performed using nano LC-ESI-MS/MS. The MS system consisted of an Agilent 1100 nanoLC system (Agilent), PicoTip electrospray emitter (New Objective) and an Orbitrap XL mass spectrometer (Thermo-Fisher). Protein spots from the membranes were in-gel digested by trypsin (Promega) (with and without citraconic anhydride treatment) and applied to nanoLC-ESI-MS/MS. Peptides were trapped and desalted on the enrichment column (Zorbax SB C18; 0.3x5 mm; Agilent) for five minutes using $2.5 \%$ acetonitrile $/ 0.5 \%$ formic acid as eluent, then peptides were separated on a Zorbax 300 SB C18 column (75 $\mathrm{m} \times 150 \mathrm{~mm}$; Agilent) using an acetonitrile/ $0.1 \%$ formic acid gradient from 5 to $35 \%$ acetonitril within 40 minutes. MS/MS spectra were recorded data-dependently by the mass spectrometer, according to manufacturer's recommendations.

\section{Peptide synthesis}

Synthetic peptide KTVTSMDIVYALK was synthesized by solid-phase technique using a multiple peptides synthesizer (SyroII; MultiSynTech $\mathrm{GmbH}$ ) on a pre-loaded Wang resin (Novabiochem) (100-200 mesh) with Fmoc-Ne-tert-butyloxycarbonyl-L-lysine (Novabiochem). The fluoren-9-ylmethoxycarbonyl strategy was used throughout the peptide chain assembly, utilizing $\mathrm{O}$-(7-azabenzotriazol-1-yl)-N,N, $\mathrm{N}^{\prime}, \mathrm{N}^{\prime}$-tetramethyluronium hexafluorophosphate (HATU) as a coupling reagent. Cleavage of the peptides was performed by incubating the peptidyl resins with trifluoroacetic acid/H2O/triisopropylsilane (95/2.5/2.5\%) for $2.5 \mathrm{~h}$ at $0^{\circ} \mathrm{C}$. Crude peptide was purified by reverse phase HPLC on a preparative column (Prep Nova-Pak; HR C18). Molecular masses of the peptide were confirmed by mass spectroscopy on a MALDI TOF-TOF using an Applied Biosystems 4800 mass spectrometer.

\section{PEAKS and peptide identification}

Immunoblot positive bands from frozen and FFPE tissues, were analyzed by mass spectrometry (nano LC-ESI-MS/MS), using a Thermo Orbitrap XL with CID fragmentation. 
A database search was performed first against human proteins contained in UniProtKB/TrEMBL (http://www.ebi.ac.uk/uniprot) and virus proteins contained in UniProtKB/TrEMBL separately. After that, to reduce the risk of false positive results, the search was made against a combined human and viral database within a $1 \%$ false discovery rate. The search parameters were: $20 \mathrm{ppm}$ precursor error tolerance, 0.6 Da fragment error tolerance, trypsin allowing non-specific cleavage at 1 end and a maximum of 3 missed cleaves, carbamidomethylation set as a fixed ptm, acetylation(k), oxidation (M), deamidation(NQ), formylation (K, Nterm), phosphorylation (STY) set as variable modifications.

The raw files were also processed through PEAKS Studio 8.0 (Bioinformatics Solutions Inc.) de novo and PEAKS DB modules. The parent mass error tolerance was set to $3 \mathrm{ppm}$, the fragment mass error tolerance was 0.6 Da. Carbamidomethylation of cysteine was set as a fixed modification and oxidation was set as a variable modification. The enzyme rules specified were trypsin, allowing non-specific cleavage at one end maximum and a maximum of three missed cleavages per peptide. The database searched was trEMBL (version is 2016_09). Only human and polydnaviridae proteins were searched, 1109386 protein sequences were searched along with a decoy database containing an equal number of proteins.

\section{Results}

Gram positive staining

We Gram stained 21 different types of human liver specimens. We initially chose the liver, since this organ is the bio-chemical processing centre and the cross road of microbial invasions of the human body.

Gram positive blue granules were diffusely and ubiquitously expressed in all tested human liver samples, including unaffected liver samples with no histological lesions. These blue granules were absolutely distinct from common pigments, such as lipofuscin, and different from gram positive bacilli that were used as controls. The granules had a typically fine granular aspect, similarly to the one present in the amoebas infected by Mimiviruses, as reported by the French authors ${ }^{6}$. Figure 1 (premise picture) illustrates Gram positive granules that are Mimiviruses infecting amoebas. The permission to use this image was kindly provided by Prof Bernard La Scola.

In the human liver cells, this fine blue granularity was detected in the cytoplasm and nuclei (Figure 2).

To further verify the ubiquitous presence of these typical blue granules in the human cells, we also Gram stained human brain, ovary, lymph node and kidney tissues. Granules could be detected in the kidney glomeruli, but not in the renal tubules (Figure 3). The brain was intensely stained, showing a diffuse granular pattern (Figures 4A and B). The ovary did not display the gram positive granules (Figure 5). In the lymph node, Gram positive granules were absent from the germinal centres and only appeared in the paracortex (Figures 6A and B).

\section{Electron microscopy}

Subsequent electron microscopy (EM) analyses of the Gram positive human tissues confirmed the presence of cellular structures resembling Mimiviruses (Figure 7). This was exactly the same case of the French authors when they proved that the fine blue granules in the amoeba were actually Mimiviruses ${ }^{6}$. To enhance the resolution detection of the EM, we used a particular antigen retrieval solution with citraconic anhydride and heat ${ }^{7-8}$. EM analyses were conducted in two different international centres and 300 micrographs were scrutinized by operators who performed a blinded reading and were also blind to each other. The immunogold labelling assays revealed also a retroviral antigenicity associated to the structures when a mammalian anti-retroviral gag-p27 $\mathrm{MoAb}$, recognizing common epitopes among several mammalian retroviruses, was tested.

\section{Mass spectrometry}

Mass spectrometry (nano LC-ESI-MS/MS) and protein identification using PEAKS 7.5 software revealed the presence within the structures of human proteins, including conventional human

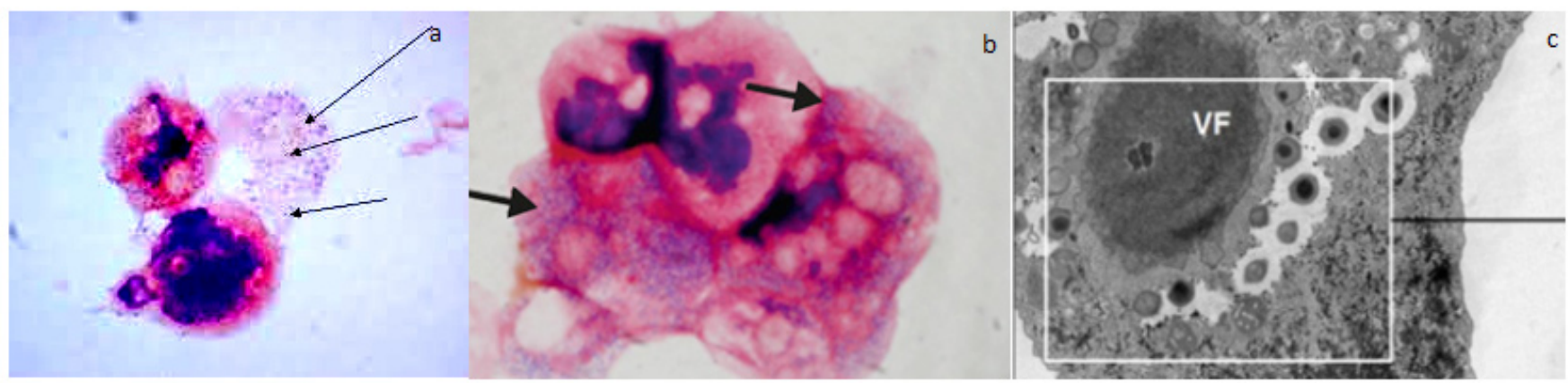

Figure 1. Premise picture. This picture illustrates Mimiviruses in the amoebas when first detected by the French authors ${ }^{6}$. Viral particles appeared as Gram-positive fine blue granules (black arrows) resembling bacterial cocci, from which the name Mimiviruses, was derived, i.e. Mimicking microbes. The blue gram positive granules in the cytoplasm of the amoeba (A and $\mathbf{B})$ proved to be Mimiviruses and not bacteria when viewed using electron microscopy $(\mathbf{C})$. Permission to use this picture was kindly provided by Prof La Scola Bernard. 


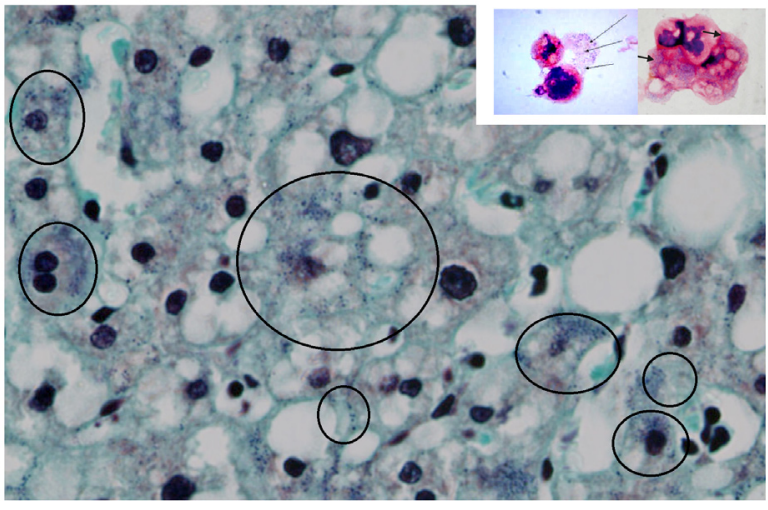

Figure 2. Human liver histochemistry. Gram staining of ahuman liver (magnification, $\times 80$ ). After the Gram stain, human liver cells displayed fine blue granules that, for didactic reasons, are enclosed in the black circles, but they can be seen scattered in the parenchyma. Note the similarities between the amoebal Mimiviruses appearing as blue granules (small picture frame and Figure 1) with the human blue granules. In the human cells, the gram positive granules appear as fine granules and are distinct from bacteria and other pigment, like lipofucsin, that is also present (brown colour).

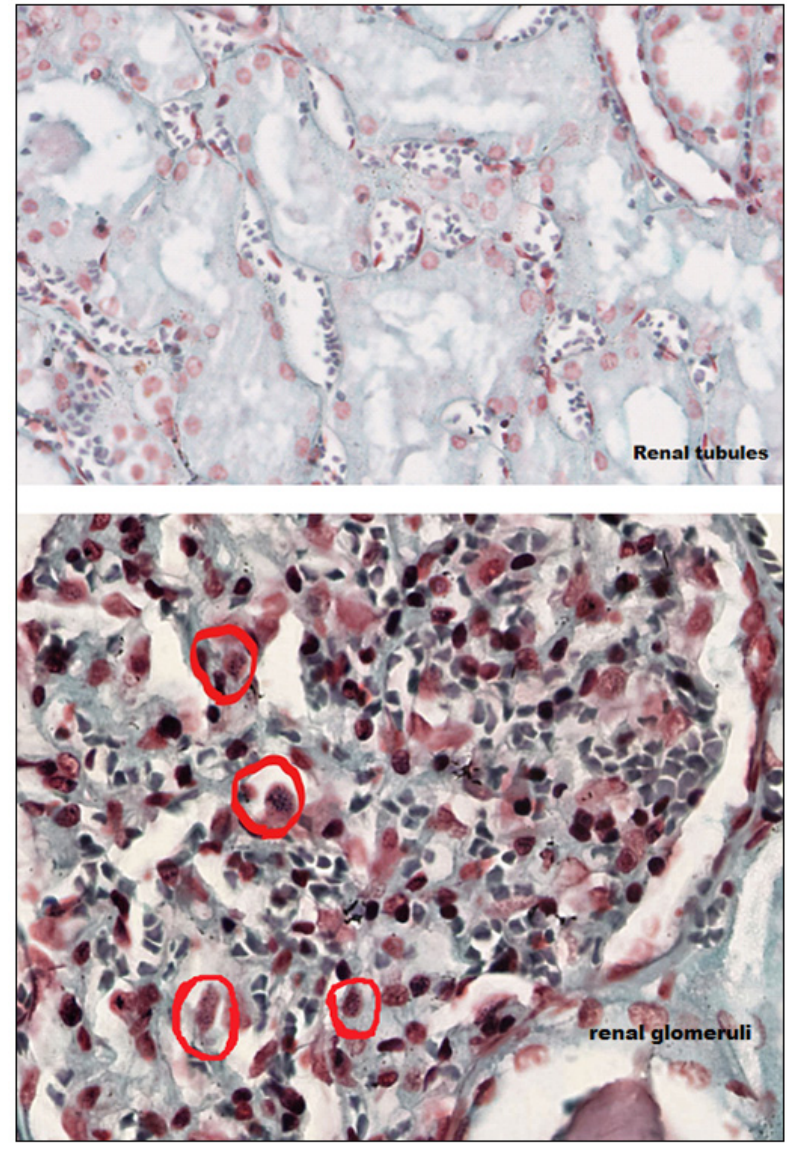

Figure 3. Human kidney histochemistry. Human kidney Gram stain. Absence of Gram positive granules in the renal tubules (magnification, $\times 43.3$ ). Gram positive granules were only present on the glomeruli, red circles $(\times 55)$.

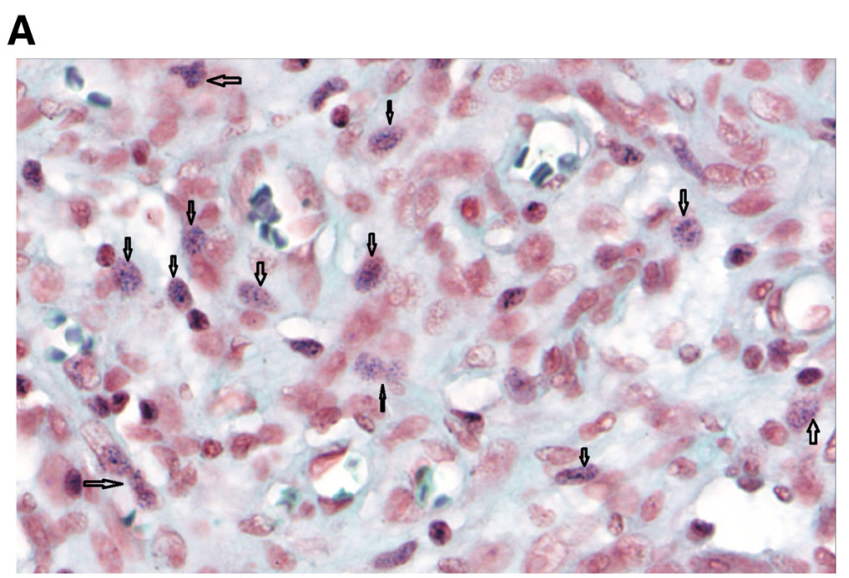

B

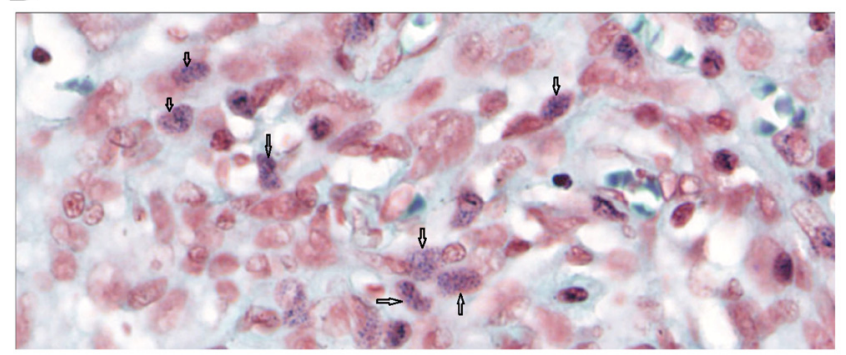

Figure 4. Human brain histochemistry. (A and B) Human brain Gram stain (magnification, $\times 80$ ). Gram positive granules were also present in the brain. Black arrows indicate the intracellular blue granules.

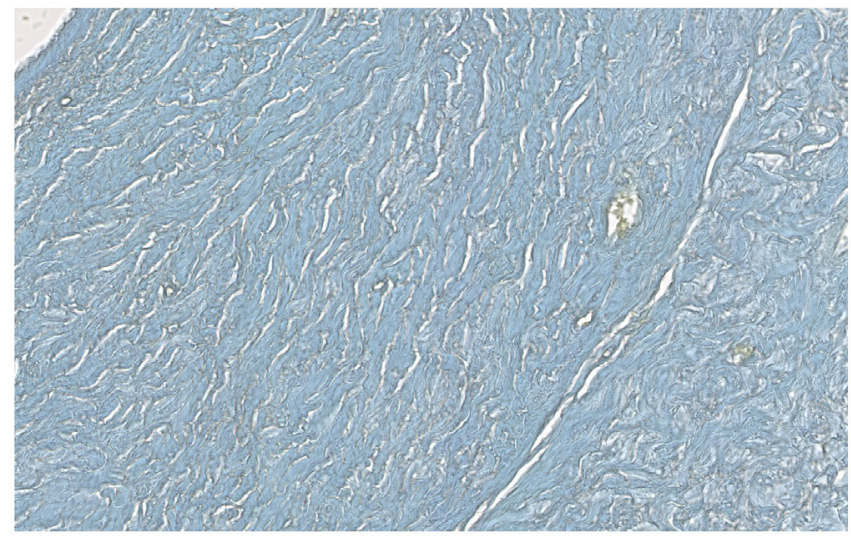

Figure 5. Human ovary histochemistry. Absence of Gram positive granules in the ovary $(\times 20)$

histone proteins that co-existed with a histone $\mathrm{H} 4$ peptide KTVTSMDIVYALK. This manifested a distinct viral footprint of giant polydnaviruses that did not match any human sequence. In fact, the human and many other eukaryotes display in correspondence of their $\mathrm{C}$-terminus histone-H4 tail a typical and extremely conserved sequence KTVT $\underline{A M D V V \boldsymbol{V} A L K}$, with a I $\rightarrow$ V replacement and human histone $\mathrm{H} 4$ variants that have never been described $^{9,10}$. 


\section{A}

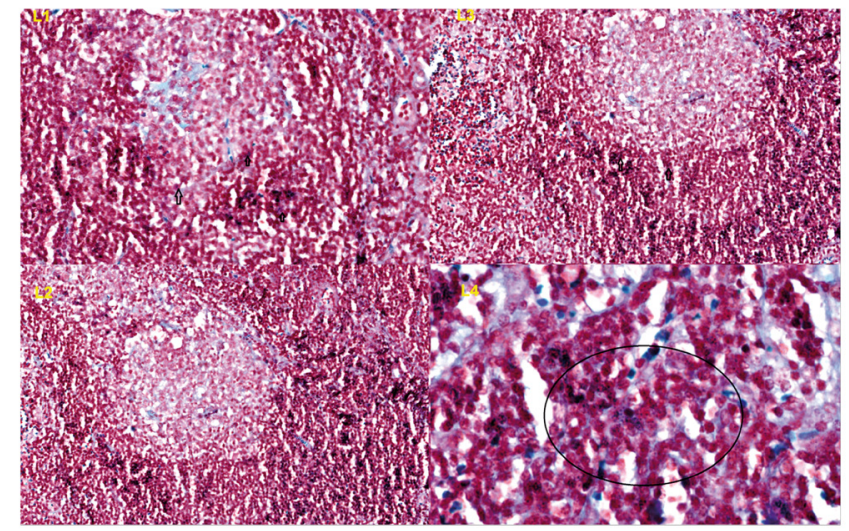

B

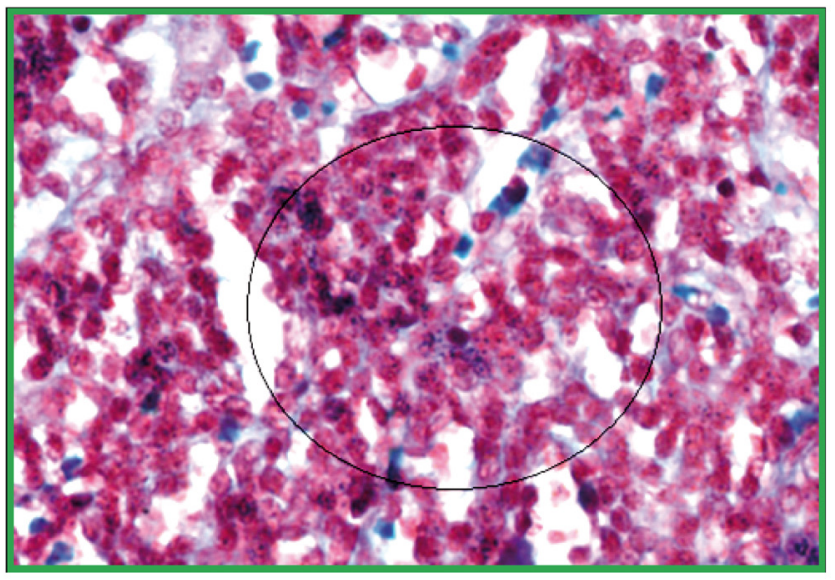

Figure 6. Human lymph node histochemistry. (A) Gram positive granules were absent in the germinal centres L1, L2, L2. Gram positive granules were specifically detected in the paracortex, outside the germinal centres, $L 4$. (B) The picture with the green frame is $L 4$ at higher magnification $(\times 80)$ with blue granules in the circle.

To rule out false positive identifications when searching just with the virus database, we combined all identified proteins in the virus database and all identified proteins in the human database into one FASTA file (Supplemental File 1). The raw files were processed through PEAKS Studio 8.0, de novo and PEAKS DB modules.

When analysing the biological samples, the peptide KTVTMDIVYALK was identified confidently in two replicates at similar retention times: 23.05 minutes in replicate one and 23.37 minutes in replicate two.

To validate our results, a synthetic peptide with the same

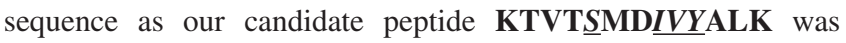
produced at the CRIBI peptide facility, University of Padua. A significant number of high intensity $b$ and $y$ ions matched the synthetic peptide spectrum. In particular, the $\mathrm{b}$ and $\mathrm{y}$ ion series from $\underline{\boldsymbol{I V Y}}$ (the part of the sequence that differs from the human protein), were prevalent in both spectra. We also performed a narrow scan in the mass range $730-740 \mathrm{~m} / \mathrm{z}$; MSMS for center mass $734.40 \mathrm{~m} / \mathrm{z}$ ( $2^{\text {nd }}$ isotope of $733.9 \mathrm{~m} / \mathrm{z} ; \mathrm{z}=2$ ); MSMS for center mass $744.40 \mathrm{~m} / \mathrm{z}$ ( $2^{\text {nd }}$ isotope of $734.9 \mathrm{~m} / \mathrm{z} ; \mathrm{z}=2$ ). The canonical human histone $\mathrm{H} 4$ and the $\boldsymbol{I V Y}$ histone $\mathrm{H} 4$ variant were both present at $\mathrm{m} / \mathrm{z}=734.907 ; \mathrm{z}=2$. A summary of the proteomics assays are reported in Figure 8-Figure 12 and in Supplemental File 2.

Three dimensional (3D) protein models of the canonical human histone $\mathrm{H} 4$ protein and the histone $\mathrm{H} 4$ isoform having the viral footprint were generated by using the Swiss Model (https://swissmodel.expasy.org/).

Dataset 1. Entire project-raw mass spectrometry data of the positive protein spots (band 1-4)

http://dx.doi.org/10.5256/f1000research.11007.d153802

\section{Discussion}

Although there are morphological and biochemical properties similar to giant viruses, the newly identified structures are possibly beyond the concept of typical viruses. The structures are 
1. HUMAN TISSUES
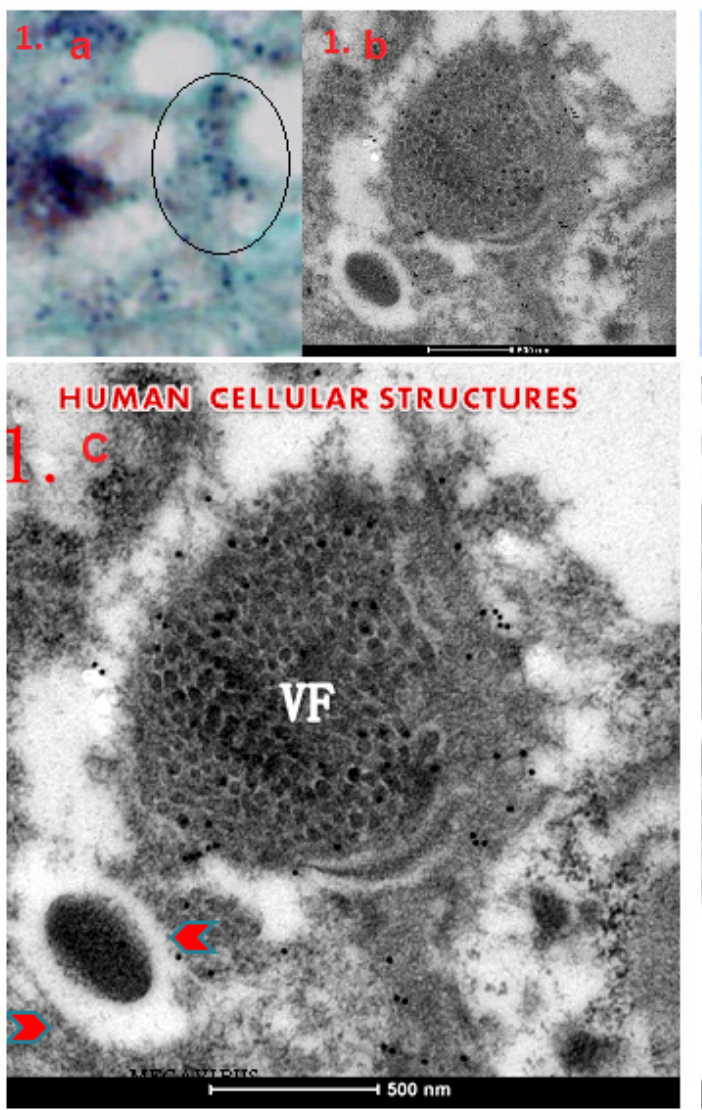

2. AMOEBAS
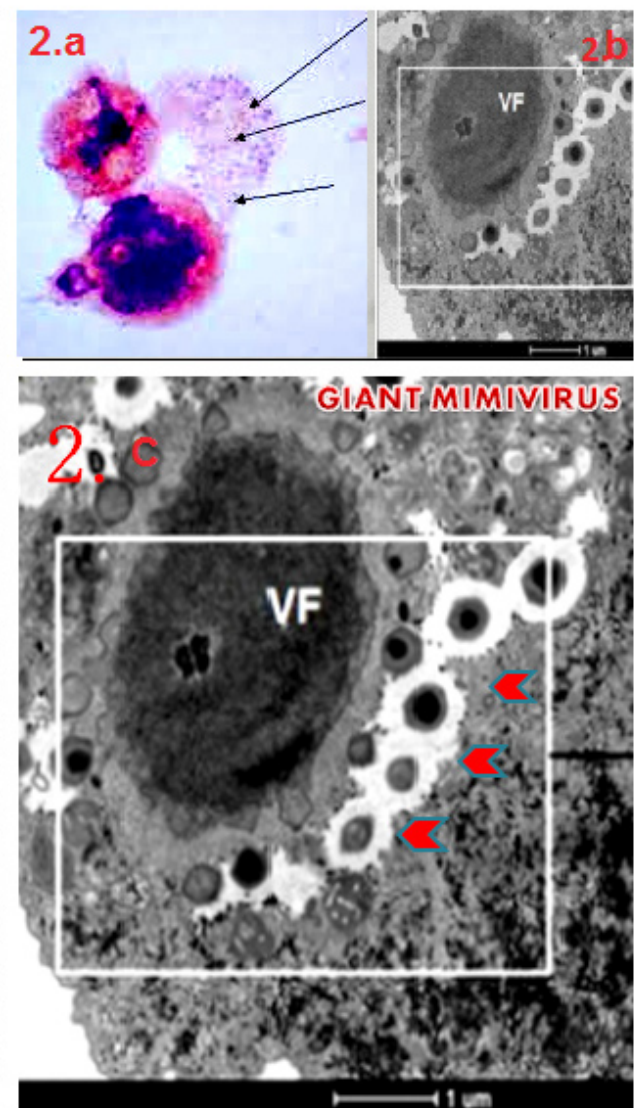

Figure 7. Representative micrograph of electron microscopy - comparative morphology. Electron microscopy (EM) of human liver tissues with the gram positive granules (black circle 1a) displayed Mimivirus-like structures at EM (1b). Similar gram positive blue granules in the amoeba (2a) are Mimiviruses (2b). Comparative morphological analysis revealed striking similarities between the human cellular structures (1c) with amoebas giant Mimiviruses (2c). Comparison of the two viral factories (VF) and the giant particles (red arrows) in the larger EM micrographs in section 1 and 2 show similarities between the two.

ubiquitous in human tissues and are not associated to a specific medical disease. We are aware that being ubiquitous does not necessarily mean that these structures are not viruses and not being infectious does not imply that they are not viruses, since viruses can be also ubiquitous and not pathogenic ${ }^{11-13}$. However, the type of the histological pattern and the mass spectrometry identification do not completely rule out that these structures could be human cellular components having a viral footprint ${ }^{14-16}$. Like mitochondria that were originally bacteria cells and still retain the bacterial features ${ }^{17-19}$, the human Mimivirus-like structures manifest an ancestral origin. Some of the histone variants detected within the human structures have the same universal motifs associated to the same function that are also used by giant polydnaviruses to manipulate their host transcription. The $\boldsymbol{I V} \boldsymbol{Y}$ histone pattern, that is present in these structures, tells the cells that some genes should be "off".

The basis for this assertion corresponds to the findings of an identical $\boldsymbol{I V} \boldsymbol{Y}$ pattern in giant viruses that represses host gene transcription $^{20-22}$. In addition, the three-dimensional analysis of the histone $\mathrm{H} 4$ that displays the $\boldsymbol{I V} \boldsymbol{Y}$ sequence shows a closed conformation that might prevent gene transcription (Figure 13). It would be interesting to trace if an evolutionary link may exist between these human cellular structures, giant viruses or archaea. The recent finding that giant viruses can integrate into modern eukaryotic genomes have motivated the fascinating and highly provocative idea that giant viruses, along with archaea and bacteria, contributed significantly to the evolution of the first eukaryotes ${ }^{23-26}$.

\section{Conclusions}

In conclusion, did we find ubiquitous giant viruses suppressing human responses or human structures with "something that was originally giant" and are not viruses any longer? The ancestral non-human nature of these structures is supported by the $\boldsymbol{I V} \boldsymbol{Y}$ histone pattern identified with mass spectrometry and by their capability to retain the Gram stain, which colour peptidoglycans. However, there are other alternative explanations for the structures that need to be considered as well. For example, the documented mammalian retroviral antigenicity does not entirely exclude the 

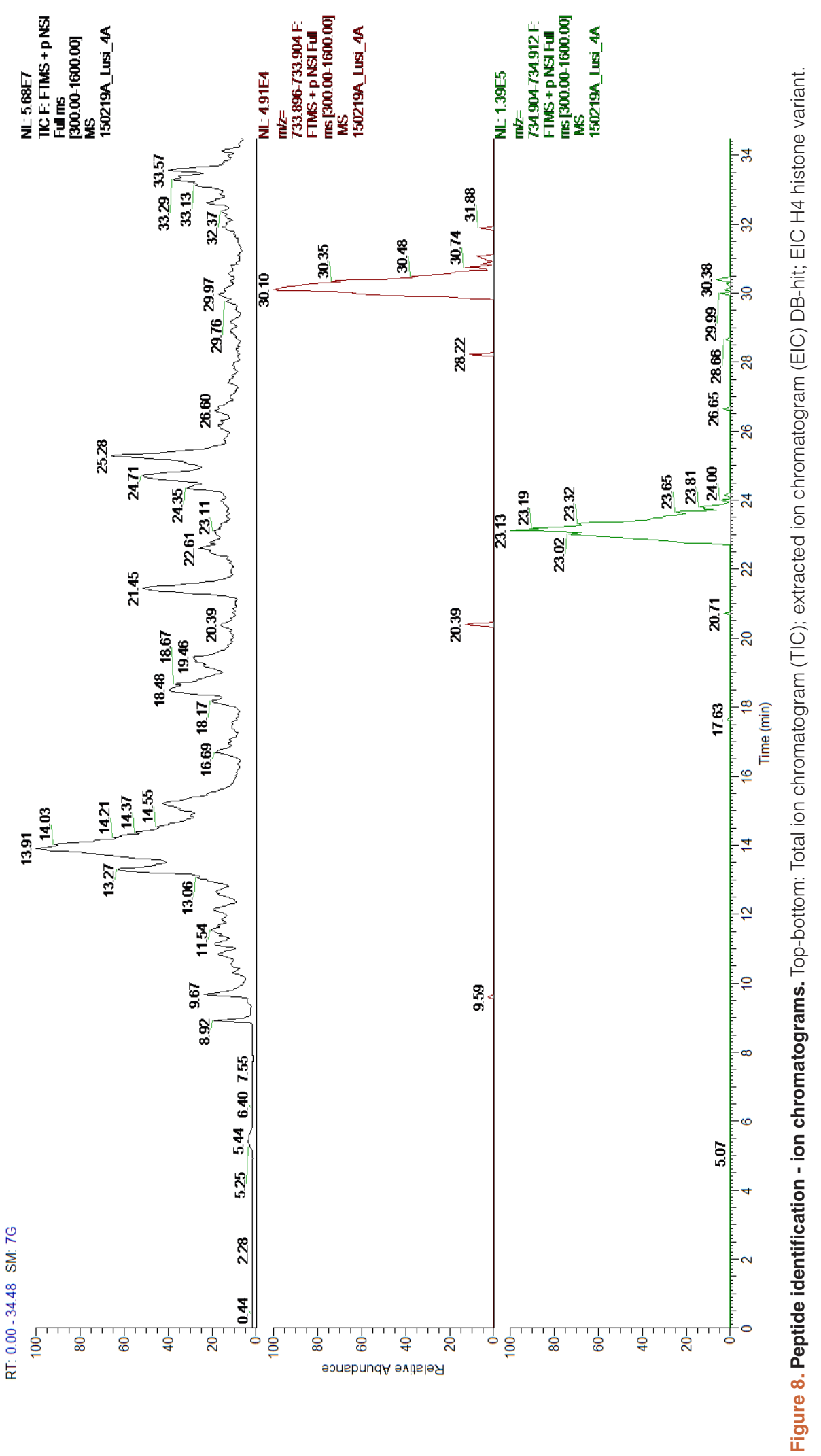

Page 9 of 20 


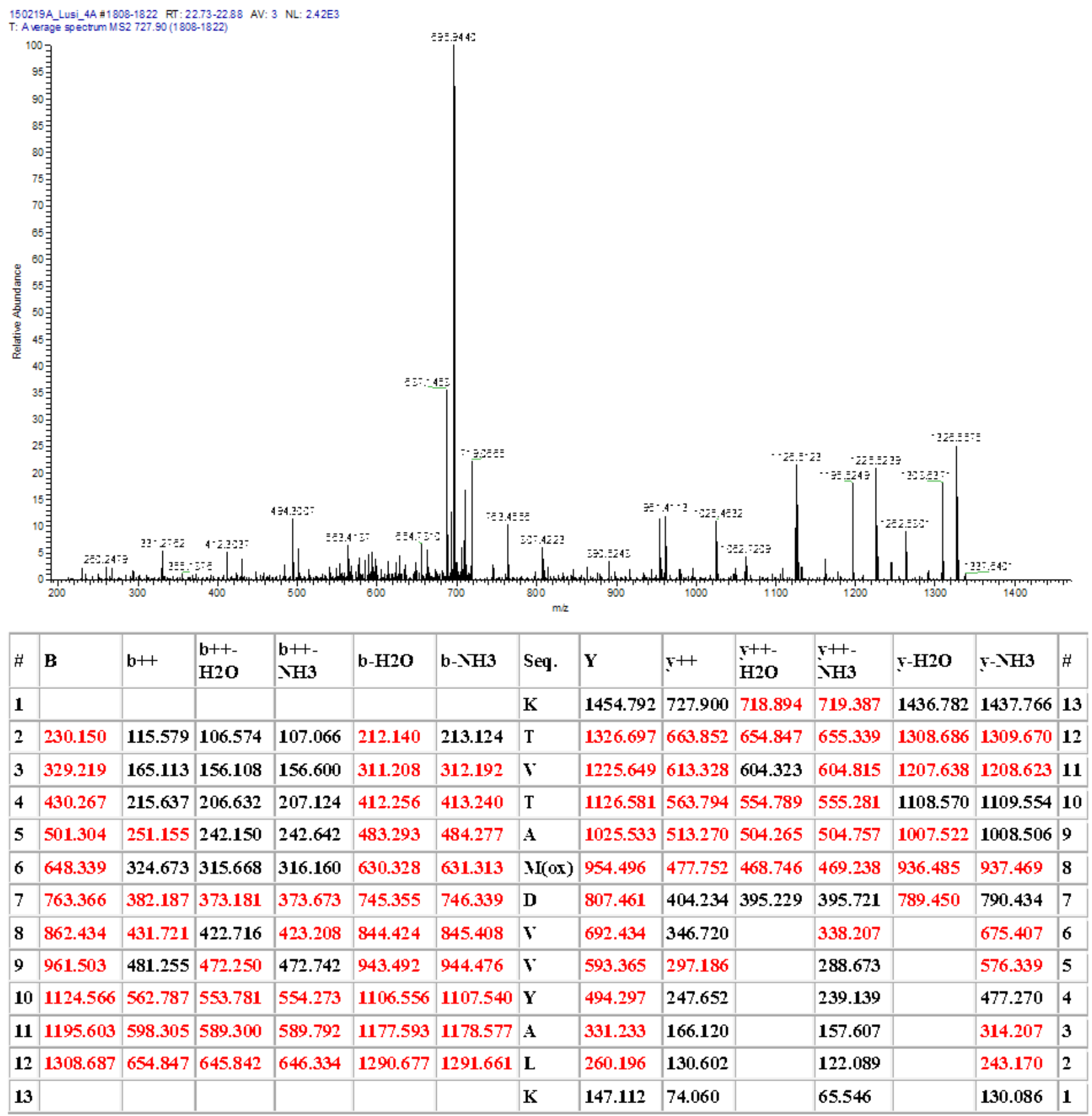

Figure 9. Mass spectrometry fragmentation pattern of the canonical human histone H4. Fragmentation table at $\mathrm{t} \mathrm{m} / \mathrm{z}=734.907 ; \mathrm{z}=2$.

possibility that these structures could represent particles formed by the concurrent activity of retro-transposons.

By the virtue of development of the science of microscopy, the ultrastructure of the cell apparatus has been established by the 1960. Since then, new structures have been sporadically reported. The main challenge when uncovering cellular components is proteomics, which can be technically much more complex than transcriptomics, and electron microscopy is perceived by some scientists as an old fashioned technique prone to artefacts. However, it is worth mentioning that the Golgi apparatus was discovered with the use of a rudimental microscope in 1898 and many scientists did not believe that the Golgi apparatus was real and instead argued that the apparent body was a visual distortion caused by staining ${ }^{27-30}$. It took almost a century to fully understand the function of the Golgi apparatus. The aim of this 


\begin{tabular}{|c|c|c|c|c|c|c|c|c|c|c|c|c|c|c|}
\hline$\#$ & B & b ++ & $\mathrm{b}++-\mathrm{H} 2 \mathrm{O}$ & $\mathrm{b}++-\mathrm{NH}^{3}$ & b-H2O & b-NH3 & Sequence. & $\mathbf{Y}$ & $y++$ & $\mathrm{y}++-\mathrm{H} 2 \mathrm{O}$ & $\mathrm{y}++-\mathrm{NH} 3$ & $\mathrm{y}-\mathrm{H} 2 \mathrm{O}$ & $\mathrm{y}-\mathrm{NH} 3$ & $\#$ \\
\hline 1 & & & & & & & K & 1468.81 & 734.91 & 725.90 & 726.39 & 1450.80 & 1451.78 & 13 \\
\hline 2 & 230.15 & 115.58 & 106.57 & 107.07 & 212.14 & 213.12 & T & 1340.71 & 670.86 & 661.85 & 662.35 & $\mid 322.70$ & 1323.69 & 12 \\
\hline 3 & 329.22 & 165.11 & 156.11 & 156.60 & 311.21 & 312.19 & V & 1239.66 & 620.34 & 611.33 & 611.82 & 1221.65 & 1222.64 & 11 \\
\hline 4 & 430.27 & 215.64 & 206.63 & 207.12 & 412.26 & 413.24 & $\mathrm{~T}$ & 1140.60 & 570.80 & 561.80 & 562.29 & 1122.59 & 1123.57 & 10 \\
\hline 5 & 517.30 & 259.15 & 250.15 & 250.64 & 499.29 & 500.27 & S & 1039.55 & 520.28 & 511.27 & 511.76 & 1021.54 & 1022.52 & 9 \\
\hline 6 & 648.34 & 324.67 & 315.67 & 316.16 & 630.33 & 631.31 & M & 952.52 & $|476.76|$ & 467.76 & 468.25 & 934.51 & 935.49 & 8 \\
\hline 7 & 763.37 & 382.19 & 373.18 & 373.67 & 745.36 & 746.34 & D & 821.48 & 411.24 & 402.24 & 402.73 & 803.47 & 804,45 & 7 \\
\hline 8 & 876.45 & 438.73 & 429.72 & 430.22 & 858.44 & 859.42 & I & 706.45 & 353.73 & & 345.21 & & 689.42 & 6 \\
\hline 9 & 975.52 & 488.26 & 479.26 & 479.75 & 957.51 & 958.49 & V & 593.37 & 297.19 & & 288.67 & & 576.34 & 5 \\
\hline 10 & 1138.58 & 569.79 & 560.79 & 561.28 & 1120.57 & 1121.56 & $\mathbf{Y}$ & 494.30 & 247.65 & & 239.14 & & 477.27 & 4 \\
\hline 11 & 1209.62 & 605.31 & 596.31 & 596.80 & |1191.61 | & 1192.59 & A & 331.23 & 166.12 & & 157.61 & & 314.21 & 3 \\
\hline 12 & 1322.70 & 661.86 & 652.85 & 653.34 & | 1304.69 & 1305.68 & L & 260.20 & 130.60 & & 122.09 & & 243.17 & 2 \\
\hline 13 & & & & & & & K & 147.11 & 74.06 & & 65.55 & & 130.09 & 1 \\
\hline
\end{tabular}

2

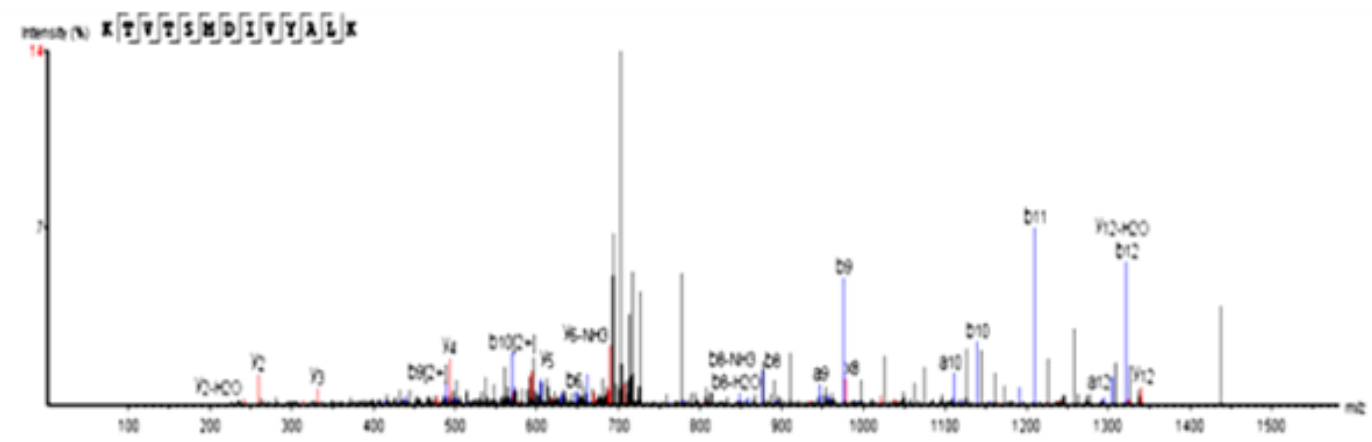

3

\begin{tabular}{|c|c|c|c|c|c|c|c|c|}
\hline B & b- $\mathrm{H} 2 \mathrm{O}$ & b-NH3 & $b(2+)$ & Sequence & $\mathrm{Y}$ & $\mathrm{y}-\mathrm{H} 2 \mathrm{O}$ & $\mathrm{y}-\mathrm{NH3}$ & $y(2+)$ \\
\hline 129.1 & 111.09 & 112.08 & 65.05 & K & & & & \\
\hline 230.42 & 212.14 & 213.12 & 115.58 & $\begin{array}{ll}\mathrm{T} \\
\end{array}$ & 1340.68 & 1322.59 & 1323.69 & 670.51 \\
\hline 329.22 & 311.08 & 312.23 & 215.09 & $\mathrm{v}$ & 1239.67 & 1221.65 & 1222.64 & 620.73 \\
\hline 430.26 & 412.26 & 413.23 & 215.09 & $\begin{array}{ll}T \\
T\end{array}$ & 1140.87 & 1122.32 & 1123.57 & 570.65 \\
\hline 517.23 & 449.29 & 500.27 & 259.23 & 5 & 1039.12 & 1321.54 & 1022.6 & 520.31 \\
\hline 648.34 & 630.43 & 631.31 & 325.11 & M & 952.52 & 934.03 & 935.4 & 476.93 \\
\hline 762.85 & 745.36 & 746.34 & 383.03 & D & 821.01 & 803.42 & 804.45 & 411.24 \\
\hline 876.46 & 858.5 & 859.42 & 439.08 & 1 & 706.53 & 688.69 & 689.63 & 353.59 \\
\hline 975.48 & 957.4 & 958.49 & 488.45 & v & 593.48 & 575.36 & 576.34 & 297.31 \\
\hline 1138.55 & 1120.63 & 1121.39 & 569.85 & $\mathrm{Y}$ & 494.56 & 476.29 & 476.93 & 247.65 \\
\hline 1209.53 & 1191.57 & 1192.62 & 605.28 & A & 331.17 & 313.22 & 314.21 & 166.12 \\
\hline \multirow[t]{2}{*}{1322.59} & 1304.79 & 1305.68 & 661.64 & L & 260.31 & 242.35 & 243.12 & 130.6 \\
\hline & & & & K & 147.11 & 129.1 & 130.09 & 74.06 \\
\hline
\end{tabular}

Figure 10. Mass spectrometry fragmentation patterns of the histone $\mathbf{H} 4$ variant (IVY). Section 1 and section 2 illustrate the fragmentation table and the spectrum (PEAKS software) of the ancestral variant of the histone H4 peptide KTVSMDIVYALK, respectively. Section 3 is the fragmentation table of the synthetic peptide that was synthesized and used to validate the KTVSMDIVYALK identification. Fragment ions that matched the spectrum in both the biological and synthetic spectrum are highlighted in colour. Red = xyz ions; blue = abc ions. The yellow region IVYALK indicates the histone $\mathrm{H} 4$ variant that was detected, along with the conventional histone $\mathrm{H} 4$, in the human cells. The same pattern IVY is also present in the histone $\mathrm{H} 4$ biology of polydnaviruses. 


\section{CONVENTIONAL HUMAN HISTONE H4 PEPTIDES}

B2RARO_HUMAN Histone H4OS=HOMOSApiens

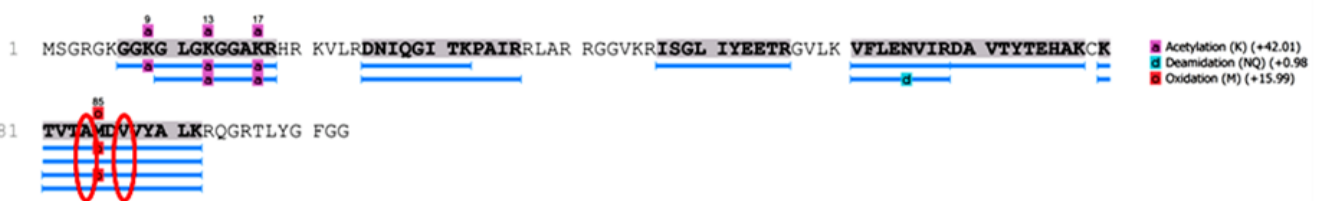

\section{HUMAN HISTONE H4 PEPTIDES WITH ANCESTRAL FOOTPRINTS}

1 MIDRPEGAKE GKGSSKVGKG QGKEKKGLEK GGKELEKGGK VSEKGGKGLE KGEKGSVKGG KGLGKGGAKR HRRSLRDNIQ व Acethoston (K) (+42.01)

81 GITKPAIRRL ARRGGVKRVS GLVYEEIRDV LKIFLKTVIH DAFHYTEHAK RKTVY SIn Y YALKRQGRKI YGFGS

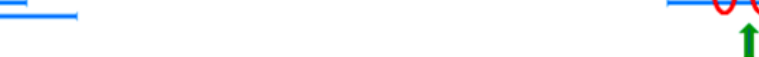

Q5ZP39 9VIRU Histoneprotein

OS=COTESI POLYDNAVIRUSES

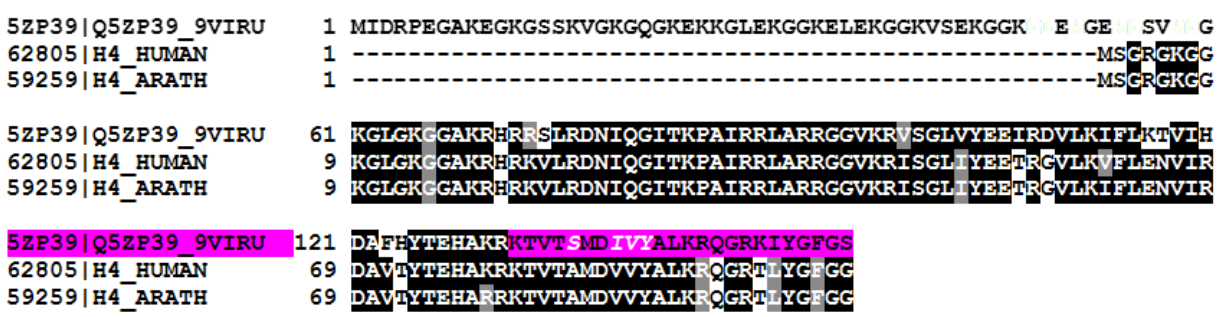

Figure 11. PEAKS Coverage view of the histone H4 peptides searched against the combined human-virus database, $1 \%$ of FDR. Section 1: The identified peptides are the canonical human histone-4 isoforms. Section 2: The histone H4 peptide KTVSMDIVYALK, indicated by the green arrow, has a unique footprint not found in any human or other eukaryotes proteins. This peptide displays the same unique sequence found in the $\mathrm{C}$-terminus of the histone $\mathrm{H} 4$ of giant polydnaviruses (purple colour in the alligmnements between eukaryotes and polydnaviruses histone $\mathrm{H} 4$ sequences).
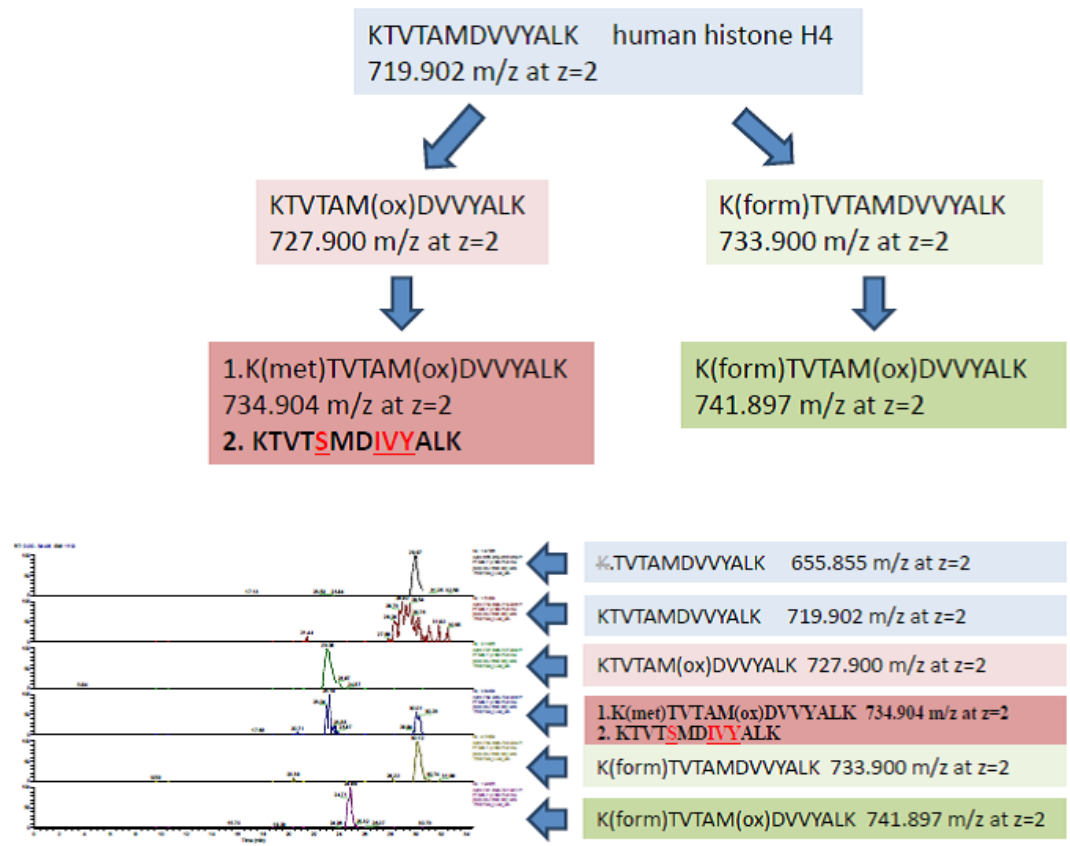

Figure 12. Proteomics data summary. Mass spectrometry identified human conventional and ancestral human $\mathrm{H} 4$ histone variants. Direct analyses and narrow scan in mass range $730-740 \mathrm{~m} / \mathrm{z}$; MSMS for center mass $734.40 \mathrm{~m} / \mathrm{z}$ ( $2^{\text {nd }}$ isotope of $733.9 \mathrm{~m} / \mathrm{z} ; \mathrm{z}=2$ ); MSMS for center mass $744.40 \mathrm{~m} / \mathrm{z}\left(2^{\text {nd }}\right.$ isotope of $\left.734.9 \mathrm{~m} / \mathrm{z} ; \mathrm{z}=2\right)$ confirmed the co-existence of the human and ancestral H4 isoforms (with the IVY pattern) at $734.905 \mathrm{~m} / \mathrm{z} ; \mathrm{z}=2$. 


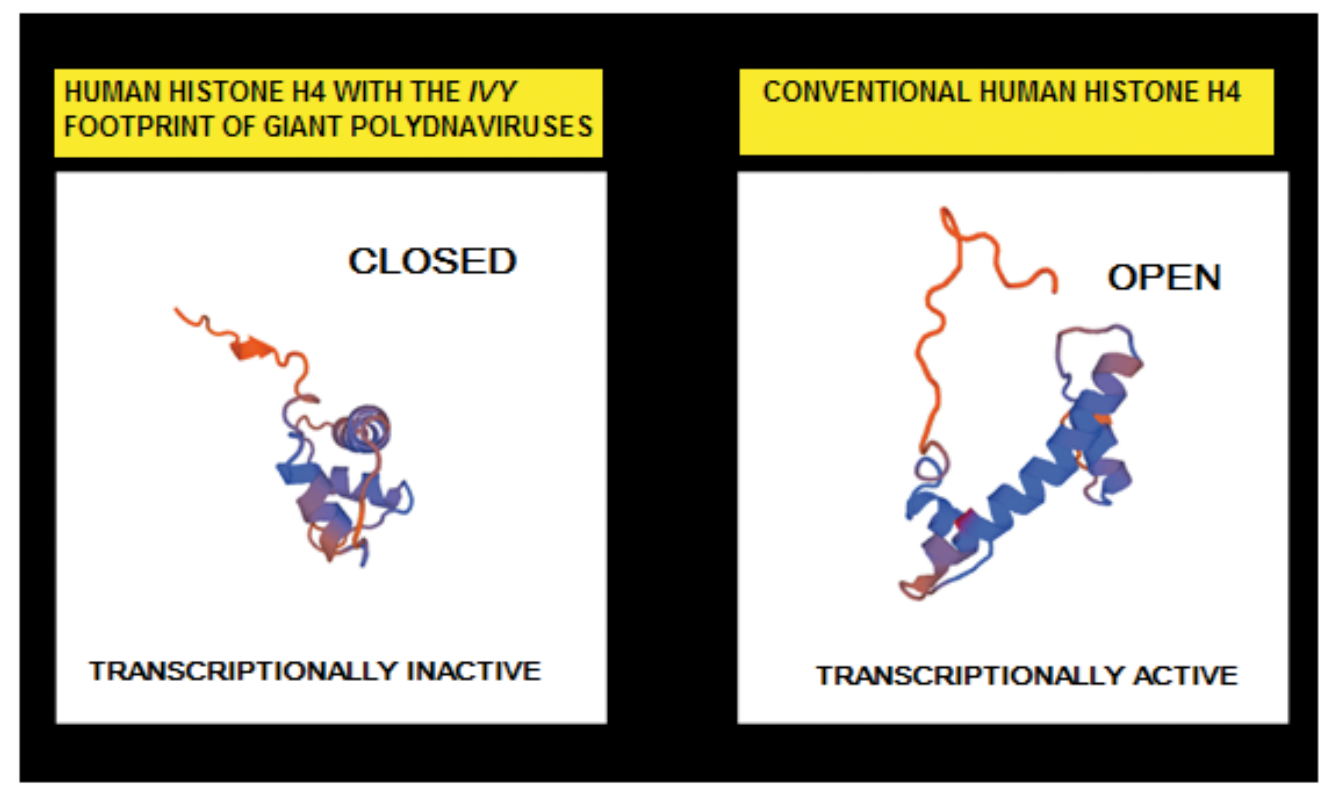

Figure 13. The newly identified human cellular structures display both canonical and histone $\mathrm{H} 4$ with an ancestral viral footprint. 3D protein structure models generated by SWISS-MODEL suggests that the human Mimivirus-like structures have a role in the regulation of transcription. The histone $\mathrm{H} 4$ with the IVY pattern have a closed transcriptionally inactive conformation. The canonical human histone $\mathrm{H} 4 \mathrm{have}$ an open conformation that is transcriptionally active.

paper is to merely report what we have found inside the human cells and offer somehypotheses. Only time and additional experiments will clarify if the identified structures are giant viruses having a retroviral antigenicity or cellular components having a viral ancestry or human retrotransposon-like elements.

\section{Data availability}

All the histological samples, slides, EM grids are available to be examined; please contact the corresponding author.

Dataset 1: Entire project-raw mass spectrometry data of the positive protein spots (band 1-4). doi, 10.5256/f1000research.11007. d $153802^{31}$.

Author contributions

EAL: conceived and led the research, protocols strategies, data analyses, manuscript; DM: mass spectrometry analyses, use of the PEAKS software; CF: Electron Microscopy Analyses; PG: Histochemistry, pathology reading, patient analyses and materials collection.

\section{Competing interests}

No competing interests were disclosed.

\section{Grant information}

This work was supported by the St Vincent Health Care Group of Dublin.

\section{Acknowledgements}

We thank Oriano Marin and his team for the synthetic peptide and the MS validation test, Grillo Rosalba for logistic support, Vittoria Balzano for technical assistance in histochemistry staining.

\section{Supplementary material}

Supplemental File 1: FASTA file containing all identified proteins in the virus database and all identified proteins in the human database.

Click here to access the data.

Supplemental File 2: Mass data and spectra of the identified histone H4 proteins.

Click here to access the data. 
1. Aherfi S, Colson P, Audoly G, et al:: Marseillevirus in Lymphoma: a giant in the lymph node. Lancet Infect Dis. 2016; 16(10): e225-34. PubMed Abstract | Publisher Full Text

2. Colson $\mathrm{P}$, Aherfi $\mathrm{S}$, La Scola B, et al.: The role of giant viruses of amoebas in humans. Curr Opin Microbiol. 2016; 31: 199-208. PubMed Abstract | Publisher Full Text

3. Colson P, La Scola B, Raoult D: Giant viruses of amoebae as potential human pathogens. Intervirology. 2013; 56(6): 376-85. PubMed Abstract | Publisher Full Text

4. Raoult D, La Scola B, Birtles R: The discovery and characterization of Mimivirus, the largest known virus and putative pneumonia agent. Clin Infect Dis. 2007; 45(1): 95-102.

PubMed Abstract | Publisher Full Text

5. Beveridge TJ: Use of the gram stain in microbiology. Biotech Histochem. 2001; 76(3): 111-8.

PubMed Abstract | Publisher Full Text

6. La Scola B, Audic S, Robert C, et al.: A giant virus in amoebae. Science. 2003; 299(5615): 2033

PubMed Abstract | Publisher Full Text

7. Moriguchi $\mathrm{K}$, Mitamura $\mathrm{Y}$, Iwami J, et al.: Energy filtering transmission electron microscopy immunocytochemistry and antigen retrieval of surface layer proteins from Tannerella forsythensis using microwave or autoclave heating with citraconic anhydride. Biotech Histochem. 2012; 87(8): 485-493. PubMed Abstract | Publisher Full Text | Free Full Text

8. Leong AS, Haffajee Z: Citraconic anhydride: a new antigen retrieval solution. Pathology. 2010; 42(1): 77-81. PubMed Abstract | Publisher Full Text

9. Talbert PB, Henikoff S: Histone variants--ancient wrap artists of the epigenome Nat Rev Mol Cell Biol. 2010; 11(4): 264-75. PubMed Abstract | Publisher Full Text

10. Kamakaka RT, Biggings S: Histone variants: deviants? Genes Dev. 2005; 19(3): 295-310.

PubMed Abstract | Publisher Full Text

11. Roossinck MJ: Plants, Viruses and the environment: Ecology and mutualism Virology. 2015; 479-480: 271-77. PubMed Abstract | Publisher Full Text

12. Pollicino T, Raffa G, Squadrito G, et al.: TT virus has a ubiquitous diffusion in human body tissues: analyses of paired serum and tissue samples. J Viral Hepat. 2003; 10(2): 95-102. PubMed Abstract | Publisher Full Text

13. Mortimer PP: Orphan viruses, orphan diseases: still the raw material for virus discovery. Rev Med Virol. 2013; 23(6): 337-9. PubMed Abstract | Publisher Full Text

14. Keck KM, Pemberton LF: Histone chaperones link histone nuclear import and chromatin assembly. Bioch Biophys Acta. 2013; 1819(3-4): 277-89. PubMed Abstract | Publisher Full Text

15. Liu WH, Churchill ME: Histone transfer among chaperones. Biochem Soc Trans. 2012; 40(2): 357-63.

PubMed Abstract | Publisher Full Text | Free Full Text
16. Li Q, Burgess R, Zhang Z: All roads lead to chromatin: multiple pathways for histone deposition. Bioch Biophys Acta. 2013; 1819(3-4): 238-46. PubMed Abstract | Publisher Full Text

17. Gray MW, Burger G, Lang BF: Mitochondrial evolution. Science. 1999; 283(5407): 1476-81.

PubMed Abstract | Publisher Full Text

18. Gray MW, Burger G, Lang BF: The origin and early evolution of mitochondria. Genome Biol. 2001; 2(6): REVIEWS1018. PubMed Abstract | Publisher Full Text | Free Full Text

19. Andersson SG, Karlberg O, Canbäck B, et al.: On the origin of mitochondria: a genomics perspective. Philos Trans R Soc Lond B Biol Sci. 2003; 358(1429): 165-77; discussion 177-9. PubMed Abstract | Publisher Full Text | Free Full Text

20. Thomas V, Bertelli C, Collyn F, et al.: Lausannevirus, a giant amoebal virus encoding histone doublets. Environ Microbiol. 2011; 13(6): 1454-66. PubMed Abstract | Publisher Full Text

21. Gad W, Kim Y: A viral histone $\mathbf{H} 4$ encoded by Cotesia plutellae bracovirus inhibits haemocyte-spreading behaviour of the diamondback moth, Plutella xylostella. J Gen Virol. 2008; 89(Pt 4): 931-8. PubMed Abstract | Publisher Full Text

22. Hepat R, Song JJ, Lee $\mathrm{D}$, et al.: A viral histone $\mathbf{h} 4$ joins to eukaryotic nucleosomes and alters host gene expression. J Virol. 2013; 87(20): 11223-30. PubMed Abstract | Publisher Full Text | Free Full Text

23. Durzyńska J, Goździcka-Józefiak A: Viruses and cells intertwined since the dawn of evolution. Virol J. 2015; 12: 169. PubMed Abstract | Publisher Full Text | Free Full Text

24. Yamada T: Giant viruses in the environment: their origins and evolution. Curr Opin Virol. 2011; 1(1): 58-62. PubMed Abstract | Publisher Full Text

25. Moreira D, López-García P: Evolution of viruses and cells: do we need a fourth domain of life to explain the origin of eukaryotes? Philos Trans $R$ Soc Lond $B$ Sci. 2015; 370(1678): 20140327

PubMed Abstract | Publisher Full Text | Free Full Text

26. Forterre $\mathrm{P}, \mathrm{Gaïa} \mathrm{M}$ : Giant viruses and the origin of modern eukaryotes. Curr Opin Microbiol. 2016; 31: 44-9. PubMed Abstract | Publisher Full Text

27. Ericsson JL: Studies on induced cellular autophagy. I. Electron microscopy of cells with in vivo labelled lysosomes. Exp Cell Res. 1969; 55(1): 95-106. PubMed Abstract | Publisher Full Text

28. Professor Camillo Golgi. Br Med J. 1926; 1(3396): 221 PubMed Abstract | Free Full Text

29. Mazzarello P, Garbarino C, Calligaro A: How Camillo Golgi became "the Golgi". FEBS Lett. 2009; 583(23): 3732-7. PubMed Abstract | Publisher Full Text

30. Bentivoglio M, Mazzarello P: One hundred years of the Golgi apparatus: history of a disputed cell organelle. Ital J Neurol Sci. 1998; 19(4): 241-7. PubMed Abstract | Publisher Full Text

31. Lusi EA, Maloney D, Caicci F, et al:: Dataset 1 in: Questions on unusual Mimivirus-like structures observed in human cells. F1000Research. 2017. Data Source 


\section{Open Peer Review}

\section{Current Peer Review Status:}

\section{Version 1}

Reviewer Report 12 June 2017

https://doi.org/10.5256/f1000research.11867.r21292

(C) 2017 Raoult D. This is an open access peer review report distributed under the terms of the Creative Commons Attribution License, which permits unrestricted use, distribution, and reproduction in any medium, provided the original work is properly cited.

\section{Didier Raoult}

Institut Hospitalo-Universitaire Méditerranée-Infection, Faculté de médecine, Aix-Marseille Université, URMITE, UM63, CNRS7278, IRD198, Inserm 1095, Marseille, France

Accept as it is

This is a fascinating paper.

This reviewer doesn't know what it means anyway. However, Marseillevirus was reported in the blood of healthy donors that fuel the hypothesis of an asymptomatic carriage of giant viruses. Wholes sequencing of the positive samples after depletion of human genes may reveal if there is viral DNA.

Competing Interests: No competing interests were disclosed.

I confirm that I have read this submission and believe that I have an appropriate level of expertise to confirm that it is of an acceptable scientific standard.

\section{Author Response 26 Sep 2017}

Elena Angela Lusi, University College of Dublin, Dublin 4, Ireland

Author Response

My previous report of unusual Mimiviruses-like structures in human cells required additional investigations. This time I will focus on clarifying their unique retroviral nature.

With a pan retroviral-PCR detection system (1) and genomic sequencing, I can be quite confident in stating that the mimivirus-like structures are human Retro-Giant-Viruses.

The retroviral sequences identified showed $\geq 90 \%$ nucleotide identity to the HERV-W species 
of human endogenous retroviruses (sequence deposited in GenBank with the accession number BankIt2050100 BSeq\#1 MF996371).

This genetic analysis further confirms the already described EM tests where an anti FeLV p27gag MoAb specifically marked the giant viruses as well as the viral factory, ( refer to the striking EM immunogold image with an anti Feline Leukemia virus protein p27gag, black dots.)

In fact, the pol genes of the viruses HERV-W are all related to other mammalian C-type retroviruses, such as murine leukemia virus, gibbon ape leukemia virus, and feline leukemia virus, on the basis of nucleotide and amino acid sequence homology (2-7).

We are facing not an archetypal human retrovirus nor even a large human retrovirus, but a human giant virus with an ancestral mammalian retroviral core.

Although sharing some morphological features with Mimiviruses, this human Retro-giant virus differ substantially from the DNA-amoebal giant viruses for its unique presence of mammalian retroviral genes (gag, pol and env).

I believe that this finding will add a new dimension to the giant viruses in general and challenge our current concepts in retrovirology. The old classification and taxonomy of retroviruses might need an update and should include the Retro-giant viruses.

Elena Angela Lusi M.D., Ph.D.

St Vincent Health Care Group-UCD, Dublin, Ireland.

\section{Suggested References}

1. Tuke PW, Perron H, Bedin F, Beseme F, Garson JA. Development of a pan-retrovirus detection system for multiple sclerosis studies. Acta Neurol Scand Suppl. 1997;169:1621.

2. Sherr C. J., Fedele L. A., Benveniste R. E., Todaro G. J. , Interspecies antigenic determinants of the reverse transcriptases and p30 proteins of mammalian type $C$ viruses. J Virol. 15(6), 1440-8 (1975)

3. M. A. Morgan, T. D. Copeland, S. Oroszlan, Structural and antigenic analysis of the nucleic acid-binding proteins of bovine and feline leukemia viruses. J Virol. 46(1), 17786 (1983)

4. G. Geering, T. Aoki, L. J. Old, Shared viral antigen of mammalian leukaemia viruses. Nature. 226(5242),265-266 (1970)

5. J. Davis, R. V. Gilden , S. Oroszlan, Multiple species-specific and interspecific antigenic determinants of a mammalian type $C$ RNA virus internal protein. Immunochemistry 12(1), 67-72 (1975)

6. Blond J-L, Besème F, Duret L, Bouton O, Bedin F, Perron H, Mandrand B, Mallet F. Molecular characterization and placental expression of HERV-W, a new human endogenous retrovirus family. J Virol. 1999;73:1175-1185.

7. M. Wunsch, A. S. Schulz, W. Kock, R. Friedrich, G. Hunsmann, Sequence analysis of 
Gardner-Arnstein feline leukaemia virus envelope gene reveals common structural properties of mammalian retroviral envelope genes. EMBO J. 2(12), 2239-2246 (1983)

Competing Interests: No competing interests.

Reviewer Report 25 May 2017

https://doi.org/10.5256/f1000research.11867.r20949

(c) 2017 Presutti C et al. This is an open access peer review report distributed under the terms of the Creative Commons Attribution License, which permits unrestricted use, distribution, and reproduction in any medium, provided the original work is properly cited.

\section{Carlo Presutti}

Dep. Biology and Biotechnology, University of Rome, Rome, 00185, Italy Milena Grossi

Istituto Pasteur Italia-Fondazione Cenci Bolognetti, Dipartimento di Biologia e Biotecnologie, Sapienza Università di Roma, Rome, Italy

The paper by Lusi et al. describes the identification of giant virus particles in human cells that seem to be quite ubiquitously and not related to any pathology. As long as I can judge, considering the fact that I am not a virologist nor an EM (electron microscopy) expert, the experiments seem to be clear and well executed. In particular the mass spectrometry experiments sound convincing.

Authors indicate that "Mimivirus-like structures identified in the human cells were ubiquitous and manifested a distinct mammalian retroviral antigenicity." However no data or experiments are shown about this interesting feature. This could be included in the paper or at least added to the discussion. The authors should also indicate why they did not go for nucleic acid identification: this could be an easier and clearer way to characterize these organisms.

The Gram-positive staining of human tissues described by the Authors is quite curious and potentially interesting, although the images presented are not so clear. Moreover, same magnification should be shown for all samples in order to better appreciate the differences among different tissues underlined by the Authors. Concerning the EM micrograph, while the virus particles inside the amoeba cell are clearly visible, is the giant particle in liver cells that indicated by the two arrowheads? If so, the similarities that can be appreciated are just the large dimensions, as they appear rather different in morphology. The Authors also refer to a retroviral antigenicity associated to the granules, as determined by staining with anti p27-gag. In the MM of the manuscript a western blot for this protein is also described, however I could not find any data about them. Since the antibody used was specific for the p27-gag from FeLV, was the crossreactivity with the human retrovirus Gag protein tested?

The data from mass spectrometry analysis look interesting, although it is not clear to me what kind of tissues were analysed.

Albeit the data would need to be improved as suggested, the findings reported appear very 
intriguing and of interest for future developments. Certainly, it seems strange that no one has ever appreciated the presence of these intracellular structures before.

Is the work clearly and accurately presented and does it cite the current literature? Yes

Is the study design appropriate and is the work technically sound? Partly

Are sufficient details of methods and analysis provided to allow replication by others? Yes

If applicable, is the statistical analysis and its interpretation appropriate? Not applicable

Are all the source data underlying the results available to ensure full reproducibility? No source data required

Are the conclusions drawn adequately supported by the results? Partly

Competing Interests: No competing interests were disclosed.

Reviewer Expertise: Molecular Biology

We confirm that we have read this submission and believe that we have an appropriate level of expertise to confirm that it is of an acceptable scientific standard.

Author Response 26 Sep 2017

Elena Angela Lusi, University College of Dublin, Dublin 4, Ireland

Author Response

My previous report of unusual Mimiviruses-like structures in human cells required additional investigations. This time I will focus on clarifying their unique retroviral nature.

With a pan retroviral-PCR detection system (1) and genomic sequencing, I can be quite confident in stating that the mimivirus-like structures are human Retro-Giant-Viruses.

The retroviral sequences identified showed $\geq 90 \%$ nucleotide identity to the HERV-W species of human endogenous retroviruses (sequence deposited in GenBank with the accession number Banklt2050100 BSeq\#1 MF996371).

This genetic analysis further confirms the already described EM tests where an anti FeLV p27gag MoAb specifically marked the giant viruses as well as the viral factory, (refer to the striking EM immunogold image with an anti Feline Leukemia virus protein p27gag, black dots). 
In fact, the pol genes of the viruses HERV-W are all related to other mammalian C-type retroviruses, such as murine leukemia virus, gibbon ape leukemia virus, and feline leukemia virus, on the basis of nucleotide and amino acid sequence homology (2-7).

We are facing not an archetypal human retrovirus nor even a large human retrovirus, but a human giant virus with an ancestral mammalian retroviral core.

Although sharing some morphological features with Mimiviruses, this human Retro-giant virus differ substantially from the DNA-amoebal giant viruses for its unique presence of mammalian retroviral genes (gag, pol and env).

I believe that this finding will add a new dimension to the giant viruses in general and challenge our current concepts in retrovirology. The old classification and taxonomy of retroviruses might need an update and should include the Retro-giant viruses.

Elena Angela Lusi M.D., Ph.D.

St Vincent Health Care Group-UCD, Dublin, Ireland.

\section{Suggested References}

1. Tuke PW, Perron H, Bedin F, Beseme F, Garson JA. Development of a pan-retrovirus detection system for multiple sclerosis studies. Acta Neurol Scand Suppl. 1997;169:1621.

2. Sherr C. J., Fedele L. A., Benveniste R. E., Todaro G. J. , Interspecies antigenic determinants of the reverse transcriptases and p30 proteins of mammalian type $C$ viruses. J Virol. 15(6), 1440-8 (1975)

3. M. A. Morgan, T. D. Copeland, S. Oroszlan, Structural and antigenic analysis of the nucleic acid-binding proteins of bovine and feline leukemia viruses. J Virol. 46(1), 17786 (1983)

4. G. Geering, T. Aoki, L. J. Old, Shared viral antigen of mammalian leukaemia viruses. Nature. 226(5242),265-266 (1970)

5. J. Davis, R. V. Gilden, S. Oroszlan, Multiple species-specific and interspecific antigenic determinants of a mammalian type C RNA virus internal protein. Immunochemistry 12(1), 67-72 (1975)

6. Blond $J-L$, Besème $F$, Duret $L$, Bouton $O$, Bedin $F$, Perron $H$, Mandrand $B$, Mallet $F$. Molecular characterization and placental expression of HERV-W, a new human endogenous retrovirus family. J Virol. 1999;73:1175-1185.

7. M. Wunsch, A. S. Schulz, W. Kock, R. Friedrich, G. Hunsmann, Sequence analysis of Gardner-Arnstein feline leukaemia virus envelope gene reveals common structural properties of mammalian retroviral envelope genes. EMBO J. 2(12), 2239-2246 (1983)

Competing Interests: No competing interests were disclosed. 
The benefits of publishing with F1000Research:

- Your article is published within days, with no editorial bias

- You can publish traditional articles, null/negative results, case reports, data notes and more

- The peer review process is transparent and collaborative

- Your article is indexed in PubMed after passing peer review

- Dedicated customer support at every stage

For pre-submission enquiries, contact research@f1000.com 